UDC 811.111: 801.8: 82.09: 81'322.5

DOI https://doi.org/10.32841/2409-1154.2019.43.3.41

\author{
Khaidari N. I., \\ Candidate of Sciences (Pedagogy), \\ Senior Lecturer of the Department of Foreign Philology \\ National Aviation University
}

\title{
SEMANTIC CLASSIFICATION OF ENGLISH RIDDLES
}

Summary. The article is devoted to revealing linguistic phenomenon of English riddles and defining semantic classification of English riddles. Riddles are referred to the ancient genre of oral folk poetry art and thus are included in the world heritage. English riddles have a lot in common with proverbs and sayings in content and artistic form. It should be noted that riddle helps to develop figurative and associative thinking, quick wits and logic. English riddles are metaphorical and non-metaphorical. It is defined that riddles are often asked in the form of question and can be descriptive, number or letter. It is revealed that to create a riddle means to make a very brief description of several inherent features of the object or phenomenon (material, shape, sound, colour, number, action, purpose, use and environment), with the help of certain vivid metaphorical images. It is defined that an important role in the riddle making process play speech figures, such as: alliteration, assonance, anaphora, repetition, parallelism, metonymy and tautology. Consequently, riddles very often are based on metaphors, metonymy and parallelism. In the language of riddles epithets, comparisons, hyperbole and tautological statements are used. Rhythm of riddles is frequently emphasized by alliteration and assonance. Rhyme and word prosody are widely used in riddles. Active composite function has dialogue, which intensifies development dynamics of main image, gives definite tension inherent therein narrative principles. One can mention special soundings of written words in riddles that make interesting, vivid symbolism of set objects, voices of insects, birds and animals. It creates a unique colouring, humorous mindedness; provide works with amusement, prompt answer to a riddle. Characteristic features of riddles as artistic form consist in combination of deep image objectness, topic concreteness within demands of abstract, generalized comparison and in keeping of certain parallel structure, artistic image with brief rendering. English riddles form power of observation, quick wits and systemic views on the world. Riddles are indispensable for the development of thinking.

Key words: riddle, solution to a riddle, classification of riddles, semantic classification of riddles, folklore, linguistic phenomenon.

Defining the problem and argumentation of the topicality of its consideration. Riddles are small witty metaphorical questions, the answer to which is their solution. Folklore of any nation is a part of the world heritage. Riddles are related to small (aphoristic) genres of folklore, and thus are included in the world heritage. They have a lot in common with proverbs and sayings in content and artistic form.

However, they also have specific features, which constitute a separate genre of folklore. Riddles are referred to the ancient genre of oral folk poetry art. They are strongly associated with human employment and attract the attention of people by their wealth, democratic essence of put into them ideas, suddenness of situations more than one century. All the above-mentioned determine the topicality of the problem under the investigation.

Analysis of recent researches and publications on the problem. In spite of the great interest of scientists to the problem of English riddles as a phenomenon (T. Green [1], A. Taylor [5], W. Peppicello [4], etc.), the problem of comparative linguistic analysis of riddles still remains unsolved.

The purpose of the research is to reveal the linguistic phenomenon of English riddles and to define semantic classification of English riddles.

The outline of the main research material. Riddles are essential component of folklore of every country. That is why riddle helps to develop figurative and associative thinking, quick wits and logic. English riddles have some literary origin, but this fact may be called into the question because of the modern look of riddles. English riddles appeared in verse in Old English poetry or in Old English literature. Manuscript in Old English (The Exeter Book) kept about 60 riddles in verse, which are related to Old English literature. For example:

\begin{tabular}{|c|c|}
\hline & \\
\hline Модðе word fræet. Me pœet & A moth ate words. \\
\hline puhte & I thought that was quite \\
\hline $\begin{array}{l}\text { wrcetlicu wyrd, pa ic pæet } \\
\text { wundor gefræegn, }\end{array}$ & $\begin{array}{l}\text { curious, that a mere worm, } \\
\text { a thief in the dark, ate what }\end{array}$ \\
\hline peet se wyrm forswealg & a man wrote, \\
\hline $\begin{array}{l}\text { wera gied sumes, } \\
\text { peof in pystro, pr] }\end{array}$ & $\begin{array}{l}\text { his brilliant language } \\
\text { and its strong foundation. }\end{array}$ \\
\hline cwide & The thief got no wiser for \\
\hline $\begin{array}{l}\text { ond pees strangan stapol. } \\
\text { Stcelgiest ne wees }\end{array}$ & $\begin{array}{l}\text { all that he fattened himself on } \\
\text { words. }\end{array}$ \\
\hline wihte & $(\mathrm{A}$ \\
\hline
\end{tabular}
pam wordum swealg.

The aforementioned riddle about the bookworm also refers to non-metaphorical as the last line says, that a creature, which ate the book did not become wiser. If it was said that the creature was wiser, then the answer to this riddle would be a man (because, after reading the book, one becomes wiser), only in this way riddle is considered to be metaphorical.

In Old English literature riddles had two goals. Firstly, to interest and intrigue the audience. Secondly, provide information, which in future will be useful for the successful usage or understanding of poetic language.

The poetic form of English riddles got the greatest popularity in the Victorian age. As a rule, riddle consisted of a few rhymed lines. In each line one of the words contained the letter, which was a part of riddle's solution. And the last line gave the greatest hint to the audience about asked object or person, for example:

My first is in tea but not in leaf

My second is in teapot and also in teeth 
My third is in caddy but not in cosy

My fourth is in cup but not in rosy

My fifth is in herbal and also in health

My sixth is in peppermint and always in wealth

My last is in drink, so what can I be?

I'm there in a classroom, do you listen to me?(A teacher)

Speaking more generally, English riddle can be confusing. Today, riddle is funny, humorous game for kids, not a literary work, as it was in Old English [4].

English riddles are metaphorical and non-metaphorical. Riddles, which contain no metaphors, are perceived not as properly riddles, but as jokes in the form of a riddle. To solve non-metaphorical riddle, it is needed not less wit, as to solve the metaphorical one. Usually, the answers to these riddles are in the eye or in the text of riddles. For example:

"What makes a Dalmatian dog spotted?" (His spots);

"Which one of our President had the largest shoes?" (The president with the largest feet) [2].

Metaphorical riddles represent the originality of the genre. Riddle is given not as a metaphorical question, but as very intricately composed question. Riddle is not a simple metaphor; it is unusual, strange metaphor, for example:

"What is it that we often return but never borrow?" (Thanks).

When this riddle is read at the first time, it can be thought that the question is about some subject. But in fact, the answer is not an object, but a word "thanks" never borrow, but always tell to someone, as a token of gratitude (that we often return). The text of the riddle contains no metaphor. However, if we know the answer, the riddle and the answer acquire a metaphorical meaning. "To return thanks" means, that "Thank you!" we say to someone, when he or she helped us in something, or in gratitude for something, in other words, we express ("return") thanks to someone.

Here are other examples of English metaphorical riddles:

"What is always coming but never arrives?"(Tomorrow);

"What is broken when you name it?" (Silence) [5].

Aristotle mentioned that riddles tell us really existing, and at the same time connect absolutely impossible. Literally understanding of riddles is not only unusual and strange, but often really ridiculous, illogical and absurd.

There are riddles in the form of question with humorous answers in English language. For example: "Some months have thirty days and some months have thirty-one days. How many months have twenty-eight days?" A hint is at February, because this month has indeed 28 days (and only once in 4 years - 29). But the answer is: "All twelve months have 28 days. Some have more as well".

In fact, English has much more riddles in the form of question, than allegory riddles. Among English riddles there are also descriptive riddles: "What has a head like a cat, feet like a cat, a tail lake a cat, but is not a cat?" (A kitten) [2].

In English, there are a lot of puzzle riddles, they are represented as groups of riddles, called "number riddles" and "riddles with usage of letters" (letter riddles). Examples of "number riddles":

"When do $\underline{2}$ and $\underline{2}$ make more than $\underline{4}$ ?" (When they make 22);

"Why is $\underline{2}$ times $\underline{10}$ the same as $\underline{2}$ times $\underline{11}$ ? "(Because two times ten is twenty and two times eleven is twenty-two (twenty, too)) [2].

English letter riddles are also commonly used in contemporary world. The most frequently used are the following ones:

"What three letters make a man of a boy?" (A, g, e: age);

"Why is the letter $\underline{A}$ like noon?" (Because it is in the middle of DAY);
"How do we know that $S$ is a scary letter?" (Because it makes CREAM SCREAM);

"What starts with $\underline{T}$, ends with $\underline{T}$, and full of $\underline{T}$ ?" (Teapot),

"From a word of five letters, take two letters and have 1" (ALONE - take the A and the L and you are left with ONE) [6].

The English language, as Ukrainian is rich in riddles of this type. We can come to conclusion that there is a group of logical and semantic riddles among English one, which includes "number riddles" and "letter riddles". Especially this type of riddles develops logic, promotes a particular type of thinking.

We see that problem riddles, as question riddles, which were mentioned above, are extraordinary real quick wits tests, which develop and activate our mental activity. And this brings together question riddles and task riddles; undoubtedly they have similarities with allegory riddles and descriptive riddles. Tasks, which are suggested in allegory riddles and in descriptive riddles require quick wits, nonstandard thinking; see unusual in usual, but in usual - unusual.

However, not only life's purpose unites these types of riddles. It should be noted, that all of them are built on paradox. From Greek "paradox", which means unexpected phenomenon, sharply contradicts sense, disagree with conventional idea. Traditionally, among English riddles, is also distinguished a group, which is called - "paradox riddles". For example: future);

"What is always before you, yet you can never see it?" (Your

"What is broken when you name it?" (Silence) [8].

We distinguished the common feature, which is inherent in all examples under examination. A lot of English riddles have questioning form ("What is...?" or "Why...?") and the answer begins with the words "because ...", for example "What does everyone have that he can always count on?" (His fingers).

By specific genre riddle is characterized by abstract and generalized sententiousness and certain levelling to national attributes.

There are a great number of terminological definitions relating to nationally coloured vocabulary in the linguistic literature. This vocabulary is represented by multiple semantic groups and operates in the English riddle, bringing a special colouring and specific nationally marked items in a general linguistic picture of the artistic structure.

First of all, it concerns their historical and geographical names. Their presence in the text permits to see belonging of the riddle to a certain territory.

Bright national colouring has different by origin vocabulary denoting persons, who represent appropriate social, and public and historical field. A special place occupies specific everyday food denoting vocabulary. Extremely rich is vegetable riddles ethnography.

To create a riddle means to make a very brief description of several most inherent features of the object or phenomenon (material, shape, sound, colour, number, action, purpose, use, and environment), with the help of certain vivid metaphorical images, for example: "What goes up and never comes down?"(Age).

Guess the riddle is possible only through logical replacement of metaphorical images by real one. Metaphorical riddles are the basis of the genre. Metaphorical images of riddles reflect the world view, environment, mode of life of certain age:

"I am a wonderful help to women

The hope of something good to come 
I harm only my slayer

I grow very tall, erect in a bed

I am shaggy down below

The lovely girl grabs my body, rubs my red skin

Holds me hard, claims my head.

That girl will feel our meeting!

I bring tears to her eyes!

What am I?"(An onion) [2].

Very often non-metaphorical are riddles, which don't name object, but describe only its quality or function:

Why can't the world ever come to an end? (Because it's round)

Most of them are expressed with questions; some of them have puzzles shape. second)

"Who succeeded the first Prime Minister of Australia?"(The

Alliteration is typical for English folk riddles:

"The beginning of eternity

The end of time and space

The beginning of every end,

And the end of every place" (The sound " $e$ ")

Anaphora is typical for some folk riddles:

"Give me food and I will live

Give me water and I will die

What am I?"(Fire)

Composition of folk riddles can be caused by reversed parallelism, when in parallels quite different, distant concepts are described. riddles:

Examples of repetition also are represented in the English folk

"If you have it, you want to share it.

If you share it, you do not have it.

What is it?"(A secret)

The most important features of the artistic genre specificity of riddles are topic concreteness, laconism, concentration of thought, extraordinary stability of tradition and imagery.

Very often metonymy is the basis of the riddle. It gives poetic mood to the whole topic and gives a special game to the riddle by possibility of its ambiguous solution. All this excites and stimulates the artistic imagination of the person who solves it:

"My step is slow / the snow's my breath

I give the ground / a grinding death

My marching / makes an end of me

Slain_by sun / or drowned in sea." (A glacier)

A lot of riddles are based on tautology:

"It cannot be seen, cannot be felt

Cannot be heard, cannot be smelt.

It lies behind stars and under hills,

And empty holes it fills.

It comes first and follows after,

Ends life, kills laughter."(Darkness) [2].

The feature of riddles is deliberate complication of the object by the widespread usage of homonyms, which stimulate an interest in, compelled to think, thoroughly analyzing the object, seeking the correct solution of a riddle.

Analyzing artistic form of riddles, one could argue, that each riddle compositionally is parallelism, the second part of which, is solution of a riddle. Sometimes riddle is built with the help of the so-called exclusion, which is close to parallelism.

Original, such which is rarely used in works of other genres, is sounding of written words in riddles. It makes interesting, vivid symbolism of set objects, voices of insects, birds and animals. It creates a unique colouring, humorous mindedness, provide works with amusement, prompt answer to a riddle.

English folk tales are characterized by artificial imagery and assonance, for example:

Thirty white horses on a red hill,

First they champ,

Then they stamp,

Then they stand still. (Teeth in your mouth.) [2].

Characteristic features of riddles as artistic form consist in combination of deep image objectness, topic concreteness within demands of abstract, generalized comparison and in keeping of certain parallel structure, artistic image with brief rendering. Metaphor is widely used in English folk riddles, for example:

"A cloud is my mother, the wind is my father, my son is the cool stream, and my daughter is the fruit of the land. A rainbow is my bed, the earth my final resting place, and I'm the torment of man" (Rain)

Extraordinary majority of metaphors here in accordance with the requirements of objectness, based on a simile of nouns, which allows with the most laconic expression form directly develop the theme and essence of the main work image.

The composite construction feature of riddles is consistent exclusion of the individual out of common one, in addition to the parallel comparison, comparison of two facts in common notional form, for example:

"I have many leaves,

But I'm not a tree.

I'm something nice,

Come and read me."(A book)

Dialogue has an active composite function in riddles. It intensifies the dynamics of the main image development and provides a narrative beginning with certain tension, for example:

- Is it black?

- No, it is red...

- But why is it white?

- Because it is green!

What is it?(A red currant)

A tendency to avoid conjunctions is noticeably expressed in riddles. A characteristic feature of the artistic form of riddles is also striving for rhythmical organization of linguistic material, for symmetry in the construction of the phrase, which often gives these works a form of short poems. Rhyme and method of sound recording by word are widely used in riddles. For example:

"It runs and runs,

But it'll never run out.

It flows. Who knows

What I'm talking about?"(A river) [2].

Conclusions. Thus, thematic range of riddles is extremely wide. First of all, it is nature, flora and fauna, human, his life, world of art and science, tools of work - from primitive to modern and technically perfect. Riddles, as a special kind of folk art, show the history of material culture of the people, living conditions, natural, social and human environment, and also the development of human knowledge and spiritual interests.

We can conclude that often English riddles are metaphorical. As a rule, it is quite difficult to guess a riddle. Firstly, one needs to have well developed figurative and associative thinking, secondly, to be very smart and to be capable of overcoming all logical difficulties, which are created by riddle. 
Characteristic features of riddles as art form, first of all, lie in combination of deep image objectness, topic concreteness within demands of abstract, generalized comparison and in keeping certain parallel structure, artistic image with brief rendering.

Consequently, riddles very often are based on metaphors, metonymy and parallelism. In the language of riddles epithets, comparisons, hyperbole and tautological statements are used. Rhythm of riddles is frequently emphasized by alliteration and assonance. Rhyme and word prosody are widely used in riddles. Active composite function has dialogue, which intensifies development dynamics of main image, gives definite tension inherent therein narrative principles. English riddles form power of observation, quick wits and systemic views on the world. Riddles are indispensable for the development of thinking.

\section{References:}

1. Green T.A., Pepicello W.J. 1979. The Folk Riddle: A Redefinition of Terms. Western Folklore. Vol. 38 (1). P. 3-20.

2. Just Riddles and More...! A free, fun collection of riddles, puzzles, games, illusions, quizzes, downloads and other activities to stimulate your brain! USA, 1999-2008. URL: http://www.justriddlesandmore. com.

3. Longman Dictionary of Contemporary English. Pearson Longman, 2009. $2081 \mathrm{p}$.

4. Peppicello W.J., Thomas A. Green. The language of Riddles New Perspectives. Ohio State University Press : Columbus, 1984. 169 p.

5. Taylor A. English Riddles from Oral Tradition. Berkeley, Los Angeles : University of California Press, 1951.

6. Дубенко О.Ю. Порівняльна стилістика англійської та української мов : посібник для студентів та викладачів вузів. Вінниця : Нова книга, 2005. $224 \mathrm{c}$.

7. Мойсієнко А.К. Без вікон, без дверей... (про національно-образний світ української загадки) Урок української. Київ, 2004. №8-9. C. 28-30.

8. Пасічник Є.А. Особливості вивчення фольклорних творів: Загадки. Методика викладання української літератури в середніх навчальних закладах : навч. посібник для студентів вищих закладів освіти. Київ, 2000.
Хайдарі Н. Семантична класифікація англійських загадок

Анотація. Стаття присвячена розкриттю особливостей мовного явища англійської загадки та визначенню іï семантичної класифікації. Загадки належать до стародавнього жанру усної народної поетичної творчості i, відповідно, входять до світової культурної спадщини. Англійські загадки мають багато спільного 3 прислів'ями та приказками за змістом і художньою формою. Слід зазначити, що загадка допомагає розвивати образне та асоціативне мислення, дотепність і логіку. Англійські загадки є метафоричними та неметафоричними. Визначено, що загадки часто ставляться у формі запитання і можуть бути описовими, цифровими чи буквеними. Виявлено, що створити загадку означає зробити дуже короткий опис кількох притаманних ознак предмета чи явища (матеріал, форма, звук, колір, число, дія, мета, використання та оточення) за допомогою певних яскравих метафоричних образів. Визначено, що важливу роль у процесі створення загадки відіграють мовленнєві фігури, такі як: алітерація, асонанс, анафора, паралелізм, метонімія та тавтологія. Отже, загадки дуже часто базуються на метафорах, метонімії та паралелізмі. У мові загадок використовуються епітети, порівняння, гіперболи та тавтологічні висловлювання. Ритм загадок часто підкреслюється алітерацією та асонансом. Рима i просодія широко використовуються в загадках. Активну композиційну функцію виконує діалог, що посилює динаміку розвитку основного образу, надає певної напруженості. Однак варто зауважити, що завдяки особливому звучанню окремих слів у загадках створюється цікава, яскрава символіка певних предметів, звуки комах, птахів і тварин. Це створює неповторне забарвлення, жартівливість; забезпечує цікавість до відгадки та швидку відповідь. Характерні риси загадок як художньої форми полягають у поєднанні глибокої об'єктності зображення, конкретності теми в межах вимог абстрактного, узагальненого порівняння та в дотриманні певної паралельної структури художнього образу з коротким викладом. Англійські загадки формують силу спостереження, дотепність і системні погляди на світ. Загадки незамінні для розвитку мислення.

Ключові слова: загадка, відгадка, класифікація загадок, семантична класифікація загадок, фольклор, лінгвістичний феномен. 